\title{
Contamination Precautions for Chemicals Which May Be Used in Drinking Water Treatment
}

\author{
Fernando B. Mainier, Leandro Pontual, Rosana Therezinha Q. de Oliveira, \\ Isabela de Oliveira Santos \\ Universidade Federal Fluminense, Escola de Engenharia, Niterói, Brazil \\ Email: fmainier@uol.com.br
}

Received 28 October 2015; accepted 19 November 2015; published 23 November 2015

Copyright (C) 2015 by authors and Scientific Research Publishing Inc.

This work is licensed under the Creative Commons Attribution International License (CC BY). http://creativecommons.org/licenses/by/4.0/

(c) (7) Open Access

\begin{abstract}
The present study aims to treat some aspects of environmental contamination under the focus of the principle of precaution, which is based on ideas and discussion about the concerns of society regarding ethics, the environment, water resources, the risk of contamination, and the uncertainties of technological applications in all areas of human knowledge. In the assessment of these scenarios it was decided to evaluate, under a critical view, the chemicals used in the treatment of drinking water, which could cause health problems, directly or indirectly, in the population. Some samples of commercial aluminium sulphate were analysed, concluding that there was a need for physical and chemical assessments to identify the origins of the raw materials used in its manufacturing process.
\end{abstract}

Keywords

Aluminium Sulphate, Contamination, Drinking Water, Principle of Precaution

\section{Introduction}

The ideas that generated principle of precaution were first expressed in the early 1970s, a time in which society was becoming concerned with ethics, the environment, the deterioration of water resources, the risk of contamination, the uncertainties and possible contamination of processed foods, and the insecurities of the technological applications in various industrial sectors.

In the vision of environmental sustainability, industrial security and the health of workers and their descendants, the term "precaution" must mean taking steps to protect human health and the environment from any pos- 
sible damage that may occur.

Industrial processes must be safe to avoid or minimise possible technological disasters. However, internationally there are different interpretations of what "safe" entails, especially when the more industrialised countries impose products and/or obsolete technologies on less developed countries.

In the view of Mainier et al. [1], in accordance with the interests and the industrial and economic philosophies, large industrial complexes and industrialised countries become co-authors of a policy of mutual interest and, in many situations, against the interests of society and environmental preservation. The large industrial complexes give the impression of not taking precautions in relation to the present or the future, according to the leaks, accidents and disasters that occur in various parts of the world. Some of these disasters can be associated with obsolete technologies and the direct or indirect use of recycling or recovery of packaging and toxic waste among others.

According to Goldim [2] the principle of precaution should not be regarded as an obstacle to social assistance activities, commercial, industrial activities or especially in terms of research. This is a current and necessary proposal as a way to safeguard the legitimate interests of each particular person and the society. The principle of precaution is fundamental in addressing current and important issues, such as the production of genetically modified foods, environmental contamination and the cloning of human beings. It must be recognized that there may be consequences harmful to society in the short or long term and thus it is essential to evaluate these risks on the basis of scientific knowledge, arguing that they are challenges to the global scientific community.

In the most comprehensive critical view, this principle is included in sustainable development, whereby it ensures that the needs of the present are met without compromising the ability of future generations to have their own needs met.

Approximately 70,000 chemicals are used by man, and roughly 40,000 are produced in commercial quantities. The preoccupation is due to the fact that an estimated total of 6000 substances have been evaluated in terms of the harmful risks they can cause for humans and the environment. However, the truth is that not all of the substances used in much of the world are evaluated and validated by toxicity tests (chronic and synchronous), epidemiological tests and echo-toxicological tests [3].

The capacity for technical innovation in relation to industrial chemicals is shown by the annual introduction of around 3000 new substances onto the international market.

It is important to note, from the point of view of the principle of precaution, that the chemical contaminant indicators (exposure and effect), when referenced to the environment, should only be evaluated when they are in the context of the study. Thus, it is vital to rethink the scientific and technological practices adopted in this process and confront them with the present social standards and desirable standards for the future based on the prevention of risks of a chemical origin.

The modern world is faced with some scientific and social contradictions. For example, it is a fact that scientific and technological advances have contributed to the reduction of the frequency of certain diseases. However, the contamination caused by certain chemicals, including disastrous events such as Bhopal [4] [5] and Seveso [6], have left traces of death and the contamination of productive soil, the air, and water.

According to Dallari and Ventura [7], those who defend the principle of precaution agree that their implementation supposes more science, more knowledge, more technologies, and more experiments, that is, more scientific and technological research.

To ensure good and applicable final results, it is essential to develop a strategy based on knowledge of all the steps of the scientific research, the analysis, the controls and the reliable technical advice as soon as possible before allowing the circulation of a product whose safety is debatable.

The present work was developed from a review of literature on the question of contamination of the environment based on the industrial route of manufacturing of aluminium sulphate used in drinking water treatment plants.

This work also aims to draw the attention of the administrators of drinking water treatment quality of toxicity of industrial routes that produce products for this purpose, because aluminium sulphate can also be used in the treatment of effluents, in the paper industry and in other areas.

\section{Water Resources}

Water resources can be utilised or developed by man in many ways, whether that is for social, recreational, in- 
dustrial, or agricultural purposes. It is evident that the progressive increase of freshwater demand is a result of the increase of the global population, the increasing number of irrigated farming areas, water for hydroelectric dams, and the use of water in various industries.

In the innocent perspective of many people in Brazil, water scarcity is not seen as a threat because the country has one of the largest river basins in the world. However, it must be considered that the country's main freshwater reserves are in the rivers of the Amazon basin, far from the major urban and industrial centres. In addition, some dams have a dual function of supplying towns with treated water and generating electric power. The problem becomes chronic when enough time there is a lack of electricity and water for public supply of a city and due to climatic seasonality the rains don't supply the large dam that have this dual function.

On the other hand, it should also be added to this critical scenario that if no sustainability criterion is applied, the large amounts of waste and various types of contamination will end up generating a gradual deterioration of the quality of the water.

In some Brazilian regions, water scarcity, especially in the north-east, is a yearly seasonal occurrence. It usually occurs due to climatic conditions associated with the lack of public planning. Now the small dams (reserve water) are full of fresh water that serves the local population, both for use as drinking water and for other activities such as washing clothes, as shown in Figure 1.

The climatic seasonality leads to completely dry dams (Figure 2 and Figure 3), bringing serious water shortage problems generating embarrassing social situations for populations faced with the progress of other cities that have water treatment plants.

The poor water quality, environmental degradation, discharge of urban and industrial wastewaters, lack of education, poverty, malnutrition and lack of basic sanitation associated with this scenario are, directly and indirectly, responsible for the high rates of diseases [8] [9].

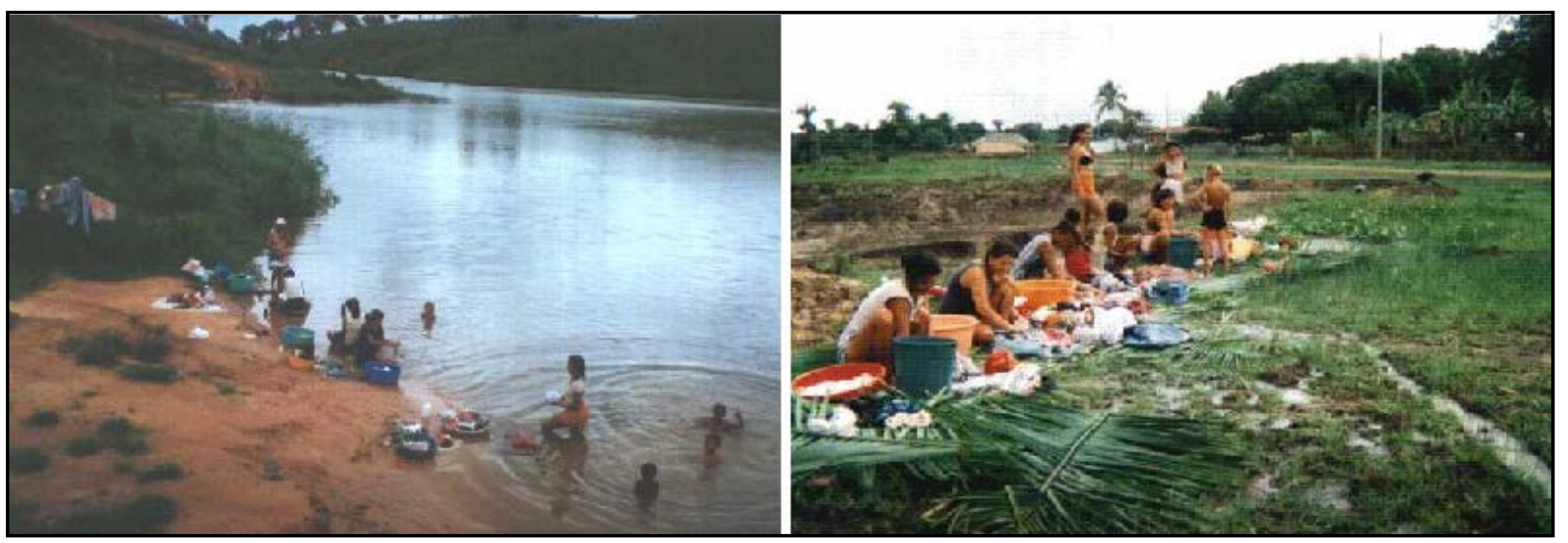

Figure 1. Overview of a dam that supplies a town where the population does their laundry and bathes in and drinks the untreated water.

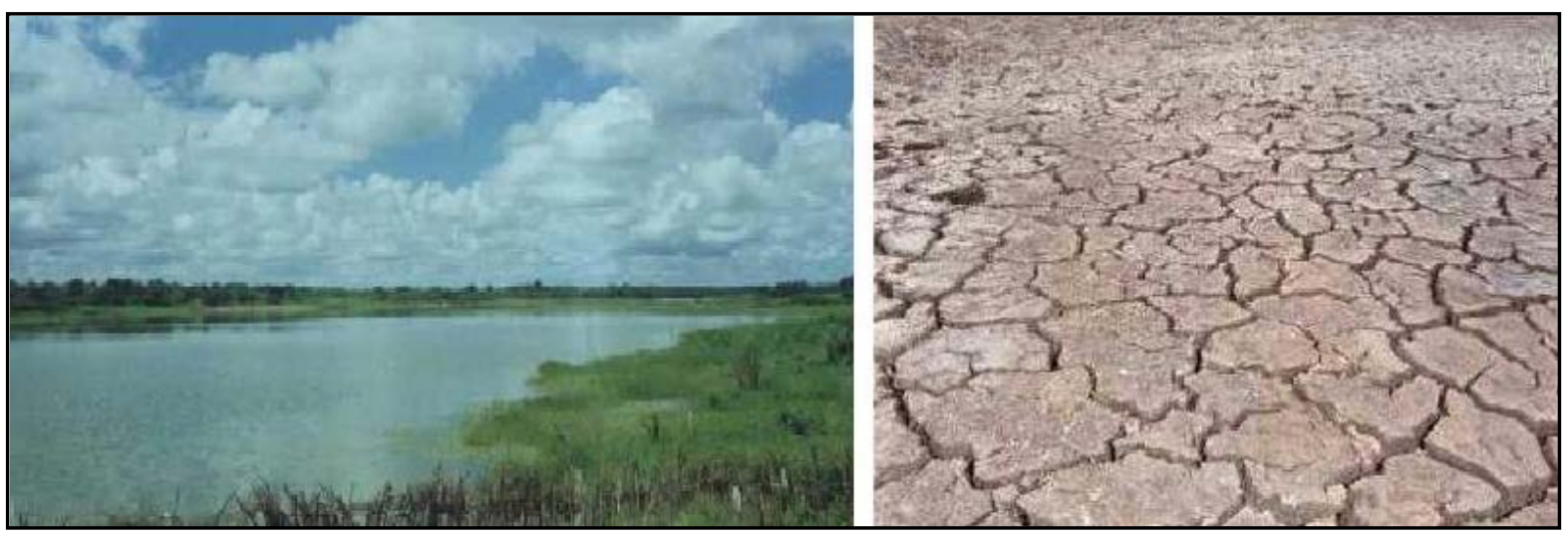

Figure 2. The dam full of water and the dam completely dry. 


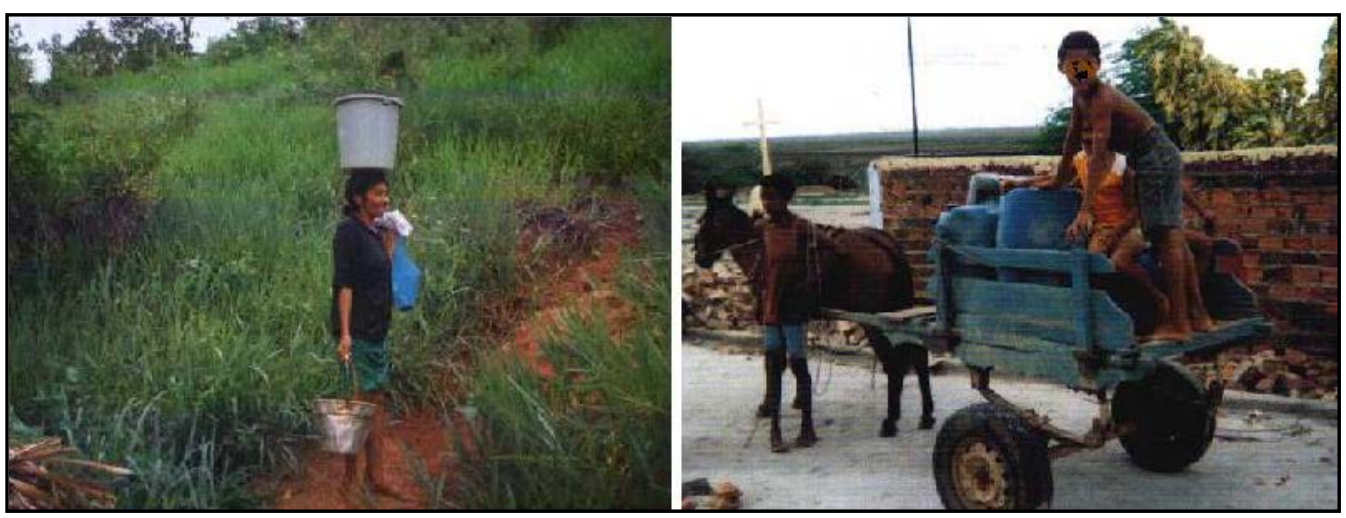

Figure 3. Untreated water transported individually or by cart.

\section{Water Quality}

Good-quality water is very important for the purposes proposed. For example, drinking water should be odourless, tasteless, colourless, and should not contain toxic substances or pathogenic microorganisms. In addition, it is essential that organic compounds, ions of toxic metals, and other contaminants in the water are below the limits set and allowed by national and international public health organisations.

Laboratory controls to check the standard of care against the applicable standards are not sufficient to ensure that the quality of water proposed for human consumption is at a suitable safety level. It is essential to know all the steps in the physical-chemical treatment of water in which continuous assessment procedures, monitoring and risk management are highlighted based on the methodology of critical points of the treatment system and domiciliary distribution.

In addition, according to Von Sperling [10], it is very important to know about the origin and management of the routes of water that reaches a treatment plant, including the planning, design, implementation and control of the procedures needed to maintain the desired water quality, because the final quality of the water will be expressed in terms of its physical, chemical and microbiological characteristics.

Finally, a guarantee of the quality of drinking water should be a citizen's right and therefore a responsibility of the State to guarantee such quality through water springs and supervision of the treatments carried out aimed at ensuring the quality of drinking water distributed to the population.

In general, the main substances traditionally used in drinking water treatments are: $\mathrm{Al}_{2}\left(\mathrm{SO}_{4}\right)_{3}$ (aluminium sulphate), polyaluminium chloride (PAC), polyelectrolyte (auxiliary flocculating), $\mathrm{Na}_{2} \mathrm{CO}_{3}$ (sodium carbonate), $\mathrm{Ca}(\mathrm{OH})_{2}$ (lime), $\mathrm{Cl}_{2}$ ) (chlorine gas) or $\mathrm{NaClO}$ (sodium hypochlorite).

In conventional water treatment plants, clarification and disinfection with these chemicals are carried out in conventional processes (flocculation, sedimentation, filtration and disinfection) in order to purify natural waters for potable purposes based on the simplified flow chart presented in Figure 4 [11].

The process consists, essentially, in removing fine particles and/or suspended colloidal, coloured organic substances and the precipitation of some anions and cations present in the water.

The clarification process comprises three distinct steps: coagulation, flocculation and sedimentation. In the coagulation process, fine particles and colloidal dispersed in water or through the addition of commercial aluminium sulphate coagulant are agglomerated. Finally, the disinfection promotes the destruction of organic matter and the micro-organisms present in water.

The coagulation process consists of the agglomeration of fine particles and colloidal dispersions in water through the addition of a commercial aluminium sulphate coagulant.

Commercial aluminium sulphate is the topic of the present work considering the preoccupation of society with the fundamentals of quality of drinking water treatments available.

\section{Aluminium Sulphate- $\mathrm{Al}_{2}\left(\mathrm{SO}_{4}\right)_{3}$}

\subsection{Aluminium Sulphate as a Coagulant}

Aluminium sulphate is one of the most common coagulants used in municipal water treatment. It promotes, 


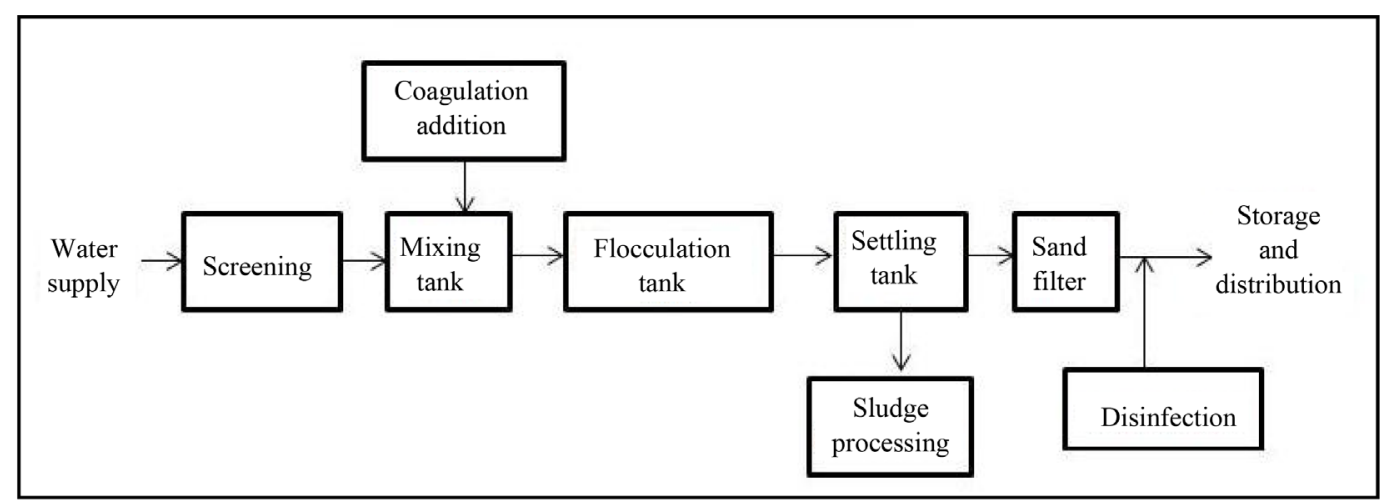

Figure 4. Conventional water treatment plant modified [11].

within certain limits, the removal of turbidity, clays, odour, colour, micro-organisms and organic pollutants.

The first scientific work on using aluminium sulphate for the treatment of water was conducted by Austen and Wilber [12] and published in 1884. The literature also refers to Schlumberger's [13] research on the action of aluminium sulphate in the presence of alkaline solutions in 1895. Subsequently, such surveys were supported by Miller [14] in 1923. Aluminium sulphate was also used by Hale [15] in 1914 and Williamson [16] in 1923 in filtrations and the removal of dyes in aqueous solutions.

When aluminium sulphate is added, water dissociation occurs, as shown in the following reaction:

$$
\mathrm{Al}_{2}\left(\mathrm{SO}_{4}\right)_{3} \rightleftarrows 2 \mathrm{Al}^{3+}+3 \mathrm{SO}_{4}^{2-} \text {. }
$$

The hydrolysis of aluminium sulphate in water has been widely studied by researchers who have presented numerous mechanisms and proposals of the chemical species present in order to identify the most likely forms of hydration. For example, the $\mathrm{Al}^{3+}$ can react with the alkalinity $\left(\mathrm{HCO}_{3}^{-}\right)$present in water and form aluminium hydroxide, as shown in the following reaction:

$$
\mathrm{Al}^{3+}+3 \mathrm{HCO}_{3}^{-} \rightarrow \mathrm{Al}(\mathrm{OH})_{3}+3 \mathrm{CO}_{2}
$$

The overall result is the reduction of the negative electrical charges in the clays, silicates, and particles (colloid and microscopic) present in the water, forming flock through the coagulant action of gelatinous aluminium hydroxide- $\mathrm{Al}(\mathrm{OH})_{3}^{-}$and consequently promoting total sedimentation. Aluminium sulphate is more effective in the $\mathrm{pH}$ range between 5.5 and 7.5. The combined addition of certain polyelectrolytes assists precipitation in the sedimentation of particles.

\subsection{Industrial Production of Aluminium Sulphate}

The aluminium sulphate industry in Brazil produces roughly a million tons a year, 55\% of which is intended for water and effluent treatment and $40 \%$ of which is intended mainly for the treatments of pulp in paper mill, textiles, lubricating compositions, fire retardants, fireproofing cloth, and as a decolourisation agent in petroleum, a deodoriser, a food additive, a firming agent, a dyeing mordant, a foaming agent in firefighting foams, and as a catalyst.

Industrial aluminium sulphate is obtained through a direct chemical reaction between aluminium oxide from bauxite ore $\left(\mathrm{Al}_{2} \mathrm{O}_{3} \cdot n \mathrm{H}_{2} \mathrm{O}\right)$ and sulphuric acid $\left(\mathrm{H}_{2} \mathrm{SO}_{4}\right)$, as shown in the following reaction and the simplified flowchart presented below in Figure 5.

$$
\mathrm{Al}_{2} \mathrm{O}_{3}+3 \mathrm{H}_{2} \mathrm{SO}_{4} \rightarrow \mathrm{Al}_{2}\left(\mathrm{SO}_{4}\right)_{3}+3 \mathrm{H}_{2} \mathrm{O}
$$

In order to maintain an appropriate size, the bauxite ore (with a low content of ferric oxide) is processed by mills and a series of rotating sieves which separate the bauxite and send it to the ore storage silo. Next, the finely ground bauxite and sulphuric acid are sent in appropriate proportions to the reactor and heated in temperature range of $100^{\circ} \mathrm{C}-120^{\circ} \mathrm{C}$. The supernatant solution, sulphate-rich aluminium, is decanted into insoluble waste disposal. The liquid solution is concentrated to form aluminium sulphate in liquid form with a concentration of 7 to $15 \% \mathrm{Al}_{2} \mathrm{O}_{3}$. For the formation of aluminium sulphate in a solid form, a solution is sent to the crystalliser. After the crystallisation of aluminium sulphate, blocks are crushed, ground, graded, and marketed as $\mathrm{Al}_{2}\left(\mathrm{SO}_{4}\right)_{3} \cdot 18 \mathrm{H}_{2} \mathrm{O}$ 


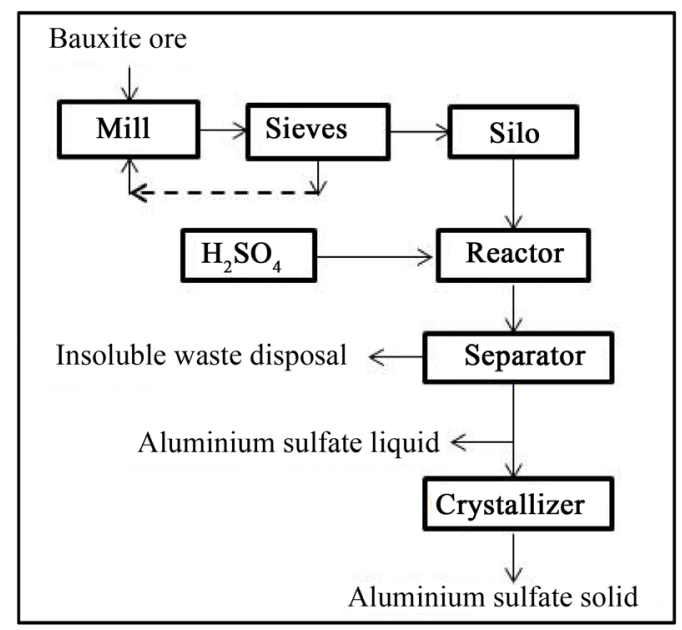

Figure 5. Simplified flowchart of the production of aluminium sulphate.

containing $17.0 \%-17.5 \% \mathrm{Al}_{2} \mathrm{O}_{3}$.

Analysis of the impurities in raw materials used in the production of aluminium sulphate is based on the caution required in the production of chemicals for the treatment of municipal water. The content of impurities in the use of aluminium sulphate in wastewater treatment isn't as important. However, for the treatment of drinking water the quality of aluminium sulphate is very important, as its use may compromise the quality of the treated water.

Bauxite $\left(\mathrm{Al}_{2} \mathrm{O}_{3} \cdot n \mathrm{H}_{2} \mathrm{O}\right)$ consists of aluminium minerals, the most important of which are gibbsite, boehmite, and diaspore. The best known impurities are $\mathrm{SiO}_{2}, \mathrm{TiO}_{2}, \mathrm{Fe}_{2} \mathrm{O}_{3}, \mathrm{MgO}, \mathrm{CaO}, \mathrm{Na}_{2} \mathrm{O}$, and $\mathrm{K}_{2} \mathrm{O}$. Furthermore, depending on the regions of mineral extraction it is possible to find some toxic metals (small quantities or traces), such as $\mathrm{Pb}, \mathrm{Cr}, \mathrm{Ni}, \mathrm{As}, \mathrm{Zr}, \mathrm{Ta}, \mathrm{V}$, or $\mathrm{Nb}$ [17]-[20].

The other input of this process is sulphuric acid. Its origin, route of manufacture, the impurities it contains, and cost are important factors in the quality of the aluminium sulphate produced and consequently in its industrial applications.

Sulphuric acid can be produced from high-purity sulphur using specific catalysts in order to generate sulphuric acid of excellent quality at a relatively high cost. The sulphuric acids from gas recovery processes $\left(\mathrm{SO}_{2}\right)$ are generally $30 \%-40 \%$ lower in cost when compared with those of high quality. It is possible to find very low-cost sulphuric acid in the international market; however it contains toxic contaminants, especially when it comes from copper produced through pyrometallurgical processes that use copper sulphide minerals. This fact is based that exist in the world over 100 furnaces producing 14 million tons of copper and about $60 \%$ of this production is being generated in countries where environmental laws are lenient with respect to $\mathrm{SO}_{2}$ from the burning of sulphide minerals [21] [22].

The recovery of the residual gases $\left(\mathrm{SO}_{2}\right.$ and $\left.\mathrm{SO}_{3}\right)$ that come out of these burners generates, directly or indirectly, more than 20 million tons of sulphuric acid. It is valid to add that most of these sulphide oresare associated with the contaminants $\mathrm{As}, \mathrm{Te}, \mathrm{Se}, \mathrm{Sb}, \mathrm{Bi}$, and $\mathrm{Pb}$, meaning that there is a strong probability of acid contamination by such toxic elements in these sulphuric acids [23] [24].

Another point which should also be highlighted in the products used in the treatment of drinking water is the "alum", a popular name and/or commercial that is often considered as a synonym for aluminium sulphate.

The term "alum" is derived from the word Latin alumen, which was erroneously applied to several substances containing aluminium sulphate and considered with having astringent properties. There are other substances also marketed as "alum" which are extremely toxic, such as: $\mathrm{K}_{2} \mathrm{SO}_{4} \cdot \mathrm{Al}_{2}\left(\mathrm{SO}_{4}\right)_{3} \cdot 24 \mathrm{H}_{2} \mathrm{O}$ (potassium alum), $\mathrm{NaAl}\left(\mathrm{SO}_{4}\right)_{2} \cdot 12 \mathrm{H}_{2} \mathrm{O}$ (sodium alum), $\mathrm{NH}_{4} \mathrm{Al}\left(\mathrm{SO}_{4}\right)_{2} \cdot 12 \mathrm{H}_{2} \mathrm{O}$ (ammonium alum), $\mathrm{KCr}\left(\mathrm{SO}_{4}\right)_{2} \cdot 12 \mathrm{H}_{2} \mathrm{O}$ (chrome alum), $\mathrm{KCr}\left(\mathrm{SeO}_{4}\right)_{2} \cdot 12 \mathrm{H}_{2} \mathrm{O}$ (chromoselenic alum), $\mathrm{FAl}\left(\mathrm{SO}_{4}\right)_{2} \cdot 12 \mathrm{H}_{2} \mathrm{O}$ (fluoro alum), and $\mathrm{CsAl}\left(\mathrm{SO}_{4}\right)_{2} \cdot 12 \mathrm{H}_{2} \mathrm{O}$ (cesium alum).

Taking as a reference $\mathrm{KCr}\left(\mathrm{SO}_{4}\right)_{2} \cdot 12 \mathrm{H}_{2} \mathrm{O}$ (chrome alum) and $\mathrm{KCr}\left(\mathrm{SeO}_{4}\right)_{2} \cdot 12 \mathrm{H}_{2} \mathrm{O}$ (chromoselenic alum), the contents of chromium and selenium, respectively, in these commercial compounds are approximately $10.40 \%$ chromium, $9.40 \%$ chromium, and $28.60 \%$ of selenium. If they are inadvertently used in water treatment the 
toxic consequences would be extremely disastrous to humans.

\subsection{Results of Quantitative Chemical Analysis of Elements Present in 12 Samples of Aluminium Sulphate (without Identification) Marketed for Treating Water}

To illustrate the quality of the aluminium sulphate used in water treatment, 12 unidentified samples of aluminium sulphate, produced both in Brazil and abroad, were collected. The quality analysis results are presented in Table 1.

The results of the investigations show low levels of $\mathrm{As}, \mathrm{Pb}$ and $\mathrm{Ba}$ (major toxic contaminants found in these samples). However, the high values of Fe and $\mathrm{K}$ may compromise the final quality of the water.

Organic matter was found in samples A, B, F, G, H, I, J, K, and L. It is not common to find organic substances in aluminium sulphate. This indicates that contaminated raw materials were probably used. The analytical method was used to determine the existing total organic carbon content in the samples. In the case of a more rigorous analysis it is important to extract this substance from the samples and search for an organic physical-chemical method for identifying them.

\subsection{Final Considerations of the Quality of Aluminium Sulphate for Use in Drinking Water Treatment}

Based on caution required for the production of chemicals for the treatment of municipal water was analysed, from the point of critical view, the raw materials used in the production of aluminium sulphate. Presently, in front of several scenarios of using aluminium sulphate, it is essential to know some points must be clarified on the basis of the principles of good manufacturing procedures, namely:

- Evaluation of aluminium oxide $\left(\mathrm{Al}_{2} \mathrm{O}_{3}\right)$ used in the process on the basis of the following points:

o identify the source, the origin, and the contaminants (inorganic or organic) of the raw material, i.e. whether it is derived from bauxite ore $\left(\mathrm{Al}_{2} \mathrm{O}_{3} \cdot n \mathrm{H}_{2} \mathrm{O}\right)$, waste products based on aluminium oxides used in adsorption processes, industrial aluminium sludge, recycling, or the re-use of unknown products that contain an operational content of $\mathrm{Al}_{2} \mathrm{O}_{3}$;

Table 1. Results of the determination of contaminants in samples of commercial aluminum sulfate.

\begin{tabular}{|c|c|c|c|c|c|c|c|c|c|c|c|c|}
\hline \multirow{2}{*}{$\begin{array}{l}\text { Determinations } \\
\text { (\% mass) }\end{array}$} & \multicolumn{12}{|c|}{ Samples } \\
\hline & A & $\mathrm{B}$ & $\mathrm{C}$ & $\mathrm{D}$ & $\mathrm{E}$ & $\mathrm{F}$ & G & $\mathrm{H}$ & I & $\mathrm{J}$ & $\mathrm{K}$ & $\mathrm{L}$ \\
\hline Arsenic (As) & 0.01 & ---- & ---- & 0.01 & ---- & 0.01 & 0.02 & ---- & 0.01 & ---- & 0.01 & 0.02 \\
\hline Barium (Ba) & 0.01 & --- & 0.01 & 0.01 & ---- & 0.01 & 0.01 & 0.01 & 0.01 & ---- & 0.01 & 0.01 \\
\hline Calcium (Ca) & 0.08 & --- & 0.05 & 0.08 & ---- & 0.08 & 0.12 & 0.05 & 0.08 & ---- & 0.09 & 0.12 \\
\hline Lead (Pb) & 0.01 & ---- & ---- & 0.01 & ---- & 0.01 & 0.03 & ---- & 0.01 & ---- & 0.03 & 0.08 \\
\hline Iron $(\mathrm{Fe})$ & 1.85 & 0.55 & 0.82 & 0.93 & 0.40 & 1.85 & 2.35 & 1.82 & 1.97 & 0.70 & 2.85 & 3.35 \\
\hline Phosphorus (P) & 1.20 & 0.18 & 0.20 & ----- & 0.25 & 1.20 & 1.80 & 0.40 & ----- & 0.45 & 0.20 & 0.87 \\
\hline Magnesium (Mg) & 0.15 & 0.12 & 0.13 & 0.09 & ---- & 0.15 & 0.25 & 0.25 & 0.52 & 0.43 & 0.19 & ---- \\
\hline Manganese (Mn) & 0.50 & 0.32 & 0.50 & 0.43 & ---- & 0.50 & 0.59 & 0.03 & 0.38 & 0.41 & 0.53 & 0.45 \\
\hline Nickel (Ni) & 0.23 & 0.34 & 0.43 & 0.32 & ---- & 0.23 & 0.55 & 0.34 & 0.98 & 0.82 & 0.61 & 0.52 \\
\hline Potassium (K) & 1.21 & 1.34 & 0.34 & 3.46 & 1.61 & 0.21 & 0.23 & 0.20 & 0.36 & 0.39 & 0.12 & 1.45 \\
\hline Sodium (Na) & 0.30 & 0.14 & 1.24 & 1.78 & 1.45 & 1.85 & 0.56 & 0.01 & 0,01 & -- & 0.01 & 0.01 \\
\hline Titanium (Ti) & 1.12 & 1.15 & 0.20 & 0.30 & 0.30 & 0.12 & 1.12 & 0.01 & 0.01 & 0.01 & --- & ---- \\
\hline Vanadium (V) & 0.01 & 0.01 & 0,01 & 0,01 & ---- & 0.01 & 0.01 & 0,01 & 0.01 & ---- & 0.01 & 0.01 \\
\hline Zirconium (Zr) & --- & 0.01 & 0.01 & 0.01 & 0.01 & ---- & ---- & 0.01 & 0.01 & 0.01 & 0.10 & ---- \\
\hline Silica $\left(\mathrm{SiO}_{2}\right)$ & 1.16 & 1.23 & 0.90 & 0.76 & 0.58 & 1.16 & 1.36 & 0.34 & 3.46 & 1.61 & 0.21 & 0.23 \\
\hline Organic matter & 0.02 & 0.01 & ---- & ---- & ---- & 0.08 & 0.67 & 1.45 & 1.85 & 0.56 & 0.01 & 0.01 \\
\hline
\end{tabular}


0 in addition, when evaluating the qualities of bauxite ore, it is important to note the possible geological contamination from phosphate rocks, fluorine-containing phosphate, and other minerals associated with $\mathrm{Ba}$, Sr, As, and radioactive elements.

- Evaluation of sulphuric acid $\left(\mathrm{H}_{2} \mathrm{SO}_{4}\right)$ on the basis of the following points:

o identifying and determining levels of various contaminants in sulphuric acid, such as As, Sb, Te, Se, etc., these contaminants are extremely toxic;

o identifying the source and origin of the sulphuric acid in function that exists currently in the international market to reuse sulphuric acid used in absorption of toxic gases and other industrial procedures where it is possible to contaminate it with organic and inorganic impurities of high toxicity.

Finally, in addition to the requirements above, commercial aluminium sulphate for the treatment of drinking water should be analysed for the following:

- determination of aluminium ions $\left(\mathrm{Al}^{3+}\right)$ represented in the form of $\mathrm{Al}_{2} \mathrm{O}_{3}$;

- determination of total insoluble;

- identification and quantitative determination of contaminant metals;

- determination of silica $\left(\mathrm{SiO}_{2}\right)$ and total Fe;

- determination of free acid;

- chromatographic and infrared analyses to identify organic contamination.

\section{Conclusions}

Based on the presentation and proposals submitted, it is concluded that:

- It is necessary to recognize that the precaution principles, applied to the treatment of drinking water, are markable and fundamental premises of responsibility and rights of society to the present and the future;

- the lack of potable water and basic sanitation in small, poor villages and in some peripheries of large cities carries with a significant increase in diseases of hydric origin in public hospitals;

- water quality is a right of the population and therefore the products used must have a quality assured and an unlimited responsibility of their manufacturers;

- it is the responsibility of manufacturers of chemicals for use in potable water to reveal the supply routes and the origins of their raw materials;

- it is essential that managers that are responsible for buying chemicals know the differences between products used for the treatment of drinking water and those used for the treatment of wastewater;

- the price of a product used in the treatment of potable water should not be the most important factor in its purchase, as the public's health may be at risk of irreversible chemical contamination from low-quality products;

- it is essential to promote the integration of environment, health and agencies of industrialization with the organized society in order to establish standards and procedures that guarantee a quality of real life;

- it is crucial to recognise the existence of the possibility of damage and contamination and the need for its assessment based on scientific knowledge and methodologies already available to the health, safety and the environment.

\section{References}

[1] Mainier, F.B., Mainier, R.J. and Cardoso, V.L.S. (2013) Clean Technology and Industrial Safe: A Right of Society. International Journal of Multidisciplinary Sciences and Engineering, 4, 1-6.

[2] Goldim, J.R. (2007) A Avaliação ética da investigação científica de novas drogas: a importância da caracterização adequada das fases da pesquisa. Revista do HCPA \& Faculdade de Medicina da Universidade Federal do Rio Grande do Sul, 27, 66-73 (in Portuguese).

[3] Augusto, L.G.S. and Freitas, C.M. (1988) O Princípio da precaução no uso de indicadores de riscos químicos ambientais em saúde do trabalhador. Ciência \& Saúde Coletiva, 3, 85-95 (in Portuguese).

[4] Allen, B. (2000) Bhopal: 15 Years on. Green Chemistry, 2, G56-G58. http://dx.doi.org/10.1039/b001772h

[5] Sarangi, S. (2002) Crimes of Bhopal and the Global Campaign for Justice. Social Justice, 29, 47-52.

[6] Mastroiacovo, P., Spagnolo, A., Marni, E., Meazza, L., Bertollini, R., Segni, G. and Borgna-Pignatti, C. (1988) Birth Defects in the Seveso Area after TCDD Contamination. JAMA (Journal of the American Medical Association), 259, 1668-1672. http://dx.doi.org/10.1001/jama.1988.03720110030030 
[7] Dallari, S.G. and Ventura, D.F.L. (2002) O Princípio da precaução: dever do estado ou protecionismo disfarçado? São Paulo em Perspectiva, 16, 53-63 (in Portuguese). http://dx.doi.org/10.1590/S0102-88392002000200007

[8] Lutz, A., Diarra, S., Apambire, W.B., Thomas, J.M. and Ayamsegna, J. (2013) Drinking Water from Hand-Pumps in Mali, Niger, and Ghana, West Africa: Review of Health Effects. Journal of Water Resource and Protection, 5, 13-20. http://dx.doi.org/10.4236/jwarp.2013.58A002

[9] Khan, T.A. (2011) Trace Elements in the Drinking Water and Their Possible Health Effects in Aligarh City, India, Journal of Water Resource and Protection, 3, 522-530. http://dx.doi.org/10.4236/jwarp.2011.37062

[10] Von Sperling, M.V. (2005) Introdução à qualidade das águas e ao tratamento de esgotos: princípios do tratamento biológico de águas residuárias, Vol. 1. DESA-UFMG, Belo Horizonte (in Portuguese).

[11] Spellman, F.R. (2013) Handbook of Water and Wastewater Treatment Plant Operations. 3rd Edition, CRC Press, Boca Raton. http://dx.doi.org/10.1201/b15579

[12] Austen, P.T. and Wilber, F.A. (1884) Report of Purification of Drinking Water by Alum. In: Cook, G.H., Ed., Annual Report of the State Geologist of New Jersey for the Year 1884, John L. Murphy, Trenton, 141-150.

[13] Schlumberger, E. (1895) Aluminum Compounds. Bulletin of the Chemical Society, 3, 13.

[14] Miller, L.B. (1923) On the Composition of the Precipitate from Partially Alkalinized Alum Solutions. Public Health Reports, 38, 1995-2004. http://dx.doi.org/10.2307/4576854

[15] Hale, F.E. (1914) The Relation between Aluminum Sulphate and Color in Mechanic Filtration. Industrial \& Engineering Chemistry, 6, 632-637. http://dx.doi.org/10.1021/ie50068a006

[16] Williamson, F.S. (1923) Basic Aluminum Sulphate. Journal of Physical Chemistry, 27, 284-289. http://dx.doi.org/10.1021/j150228a004

[17] Pagano, G., Meriç, S., de Biase, A., Laccarino, M., Petruzzelli, D., Tünay, O. and Warnau, M. (2002) Toxicity of Bauxite Manufacturing By-Products in Sea Urchin Embryos. Ecotoxicology and Environmental Safety, 51, 28-34. http://dx.doi.org/10.1006/eesa.2001.2114

[18] Castaldi, P., Silvetti, M., Santona, L., Enzo, S. and Melis, P. (2008) XRD, FTIR, and Thermal Analysis of Bauxite Ore-Processing Waste (Red Mud) Exchanged with Heavy Metals. Clays and Clay Minerals, 56, 461-469. http://dx.doi.org/10.1346/CCMN.2008.0560407

[19] Liu, X.F., Wang, Q.F., Deng, J., Zhang, Q.Z., Sun, S.L. and Meng, J.Y. (2010) Mineralogical and Geochemical Investigations of the Dajia Salento-Type Bauxite Deposits, Western Guangxi, China. Journal of Geochemical Exploration, 105, 137-152. http://dx.doi.org/10.1016/j.gexplo.2010.04.012

[20] Mayes, W.M., Jarvis, A.P., Burke, I.T., Walton, M., Feigl, V., Klebercz, O. and Gruiz, K. (2011) Dispersal and Attenuation of Trace Contaminants Downstream of the Ajka Bauxite Residue (Red Mud) Depository Failure, Hungary. Environmental Science \& Technology, 45, 5147-5155. http://dx.doi.org/10.1021/es200850y

[21] Dimitrijević, M., Kostov, A., Tasić, V. and Milosević, N. (2009) Influence of Pyrometallurgical Copper Production on the Environment. Journal of Hazardous Materials, 164, 892-899. http://dx.doi.org/10.1016/j.jhazmat.2008.08.099

[22] Moskalyk, R.R. and Alfantazi, A.M. (2003) Review of Copper Pyrometallurgical Practice: Today and Tomorrow. Minerals Engineering, 16, 893-919. http://dx.doi.org/10.1016/j.mineng.2003.08.002

[23] Piret, N.L. (1999) The Removal and Safe Disposal of Arsenic in Copper Processing. JOM, 51, 16-17. http://dx.doi.org/10.1007/s11837-999-0150-3

[24] Taylor, P.R. and Putra, T.A.R. (2014) Pyrometallurgical Processing Technologies for Treating High Arsenic Copper Concentrates. In: Mackey, P.J., Grimsey, E.J., Jones, R.T. and Brooks, G.A., Eds., Celebrating the Megascale: Proceedings of the Extraction and Processing Division Symposium on Pyrometallurgy in Honor of David G.C. Robertson, John Wiley \& Sons, Hoboken, 197-212. http://dx.doi.org/10.1002/9781118889657.ch17 